\title{
A Framework of Theoretical Perspectives in Purchase Decision of Jewelry from Social Networking Sites
}

\author{
[ Paramin Chuangemanee, Prattana Punnakitikashem* ]
}

\begin{abstract}
Previous studies show that social networking has tremendous effect on our daily life and consumer behavior. It has been rapidly grown in a few year in Thailand. Many companies have use social network as platform to offer products. Jewelry is an interesting product containing special characteristic. There are increasingly numbers of online stores were selling jewelry products in social networking sites. This study explores the factors which influence purchase decision of jewelry items from social networking by employing value framework theory, which consists of functional values, emotional values, and social values. The study proposes the conceptual framework for purchasing decision of jewelry from social networking sites, which is crucial for jewelry business.
\end{abstract}

Keywords - jewelry, social networking, value framework

\section{Introduction}

The jewelry has long been embedded in the human culture as a symbol of prosperity, wealth and fortune. It usually was worn in daily life for many people. As a result, jewelry has become an essential part of people's daily use. In the past, designs and manufacturing methods were different in each area depending on local traditions. Presently, Thai jewelry manufacturers have also been transformed from original equipment manufacturers (OEMs) to original design manufacturers (ODMs) and many have also established their own brands, as evidenced by a strong presence of several new jewelry brands in the social networking. This channel is better and cheaper to display the product information from sellers, and it is easy to access directly by consumers, especially product explorations, comparisons and information sharing.

Nowadays, the world has fully entered the social networking era. Because the development of communication technology likes $3 \mathrm{G}$ and the upcoming $4 \mathrm{G}$ (available in Thailand 2016) has been a key driver to the continuous increase in the internet usage and social networking. It is no surprise that social networking has become an essential part of our everyday life, providing that some people use smartphone to communicate through social networking.

\section{Paramin Chuangemanee}

College of Management, Mahidol University Thailand

\section{*Prattana Punnakitikashem}

College of Management, Mahidol University Thailand

\begin{abstract}
Social network is now booming in Thailand and it has continuously been increasing growth each day. Social networking provides many people to communicate with each other, and they can share photos, video and more with people you know such as the family and friends. It creates a new marketplace for retail business. Consequently, the social networking is significantly changing our life and the relationship between consumers and sellers. Customers can easily obtain information about goods and services for geographically large and dispersed populations, who have bought and used possible products or services. There are increasingly numbers of online stores were selling jewelry products in social networking sites. Some of these stores were obviously selling well, some of them were not, or were just self-sufficient. To understand the customer on how they made decision to purchase jewelry would promote the jewelry business to create or develop the appropriate business strategies to customer needs. Therefore, this study is crucial study for jewelry business.
\end{abstract}

\section{Literature Review}

\section{A. Social networking sites}

Ellison [1] defined the social networking sites (SNSs) as the web-based services that allow individuals to create a public profile, creates a list of users whom to share the connections, views and travesty of their list of connections within the system. In the other definitions, social networking sites (SNSs) is a platform to build a social network or social relations among people who share similar interests, activities, background or real-life connections. A social network service consists of a representation of each user profile, his or her social links, and a variety of additional services such as career services [2]. In addition, most social networking sites support the maintenance of pre-existing social networks, but others help stranger's connection based on shared interests and political views, or activities. Some sites cater to diverse audiences, while others attract people based on a common language or shared race, gender, religion, or nationality as identities. The social network site provides various types of social interactions such as message posting, information exchange and contact management. In addition to basic social interaction features, other forms of social interactions such as consumers' numerical ratings of products and the number of online reviews have been found to be correlated with sales [3]. Social networking sites allow users to share ideas, pictures, posts, activities, events, and interests with people in their network. The term of social network sites was to describe this phenomenon, social 
networking sites also appears in a public discourse, and the two terms were often used interchangeably [1].

In Thailand, a statistical report has demonstrated that Facebook was the leader with 30 million active users, the demographic notes that $52 \%$ of Facebook users were male, while $48 \%$ were female. The second social networking site was YouTube at 26.2 million active users, the demographic shows that 50.8 of the users were male and $49.2 \%$ female. It is followed by Twitter and Instagram at 4.5 million and 1.7 million respectively. For Instagram, the report shows that Thailand was the second popular city on Instagram platform and the demographic shows more female users at $65 \%$, while $35 \%$ of users were male. On deep down into the Facebook statistics; moreover, there are 30 million active users per month, Most of all, there are 28 million users are active on mobile devices. Interestingly, the report also shows that $66 \%$ of users had login-in by mobile devices every day, it has nearly 20 million users [4]. The statistical report is an indicator that Thai people have entered the mainstream of social networking and integrated it into their daily life.

\section{B. Value framework}

The value framework is a contemporary model that explains why consumers prefer a specific product or service. The framework was developed by Sheth, Newman \& Gross [5], was evaluated according to functional, emotional, and social values. Value framework guides to understand consumers' behavior and preference on goods or services. The customers pay only for what is of use to them and gives them value [6]. It is very important for business to understand consumer behavior properly and choosing a marketing strategy accordingly. Value is widely discussed in the practitioner literature, and the values have been studied in consumer behavior. Values are crucial for understanding the relationship with consumer behavior [7].

1) Functional value: The functional value was defined as a perceived utility acquired from an alternative's capacity for functional, utilitarian, or physical performance [5]. A functional value may be derived from characteristics or attributes. A functional value can also be described as a benefit obtained from the product related to its performance, reliability, price and soundness [8]. An assumption that preferences are made by taking a functional value into account was derived from the financial pragmatic theory. This theory suggests that preferences are made to obtain a maximum benefit in a situation. A consumer who has decided to buy a product or not makes a decision by focusing on whether he needs the features of that product or not [5]. Other authors have also suggested that viewing a value as a trade-off between quality and price was too simplistic [9]. A functional value can be measured in either monetary or functional terms. In addition, the functional value is explained by price utility and quality that are the key importance of customer decision-making [10].

Price utility (PU): The price utility was derived from the perceived efficient use of money. Price was an attractive factor to most consumers when they make buying decisions. Biswas \& Blair [11] concluded that the price discount could affect consumers' price belief, and eventually affect their shopping intentions. Wagner [12] claimed that the consumer were focused on discount seeking behavior and was described as consumers' desire for inexpensive shopping opportunities. Pricing should reflect the importance of a customer, customer sensitivity, market position in different niches, competitor pricing, and costs to serve [13]. Miller [14] pointed out that the virtual online stores allowed to save on the cost of rent, store installation, decoration and personnel. Therefore, consumers were able to get the product at a lower price. When consumers discover that they can get the same quality product at a lower cost, purchase intention would then be generated. Therefore, price utility was an aspect of functional value that contributes positively to purchase intention.

Quality (QUA): Woodruff [15] commented the structural properties of the customer value construct based on quality, which lead to higher order consumption consequences. Customer goals operated at the top of this hierarchy of value, providing the contextual frame for attaching importance to various consumption experiences [16]. Albrecht [17] stated that the only thing that matters in the new world of quality was deliver customer value. Perceptions of value represented a tradeoff between the quality and benefits of the product by paying the price [18]. Customer value was market perceived quality adjusted for the relative price of your product [19]. Ostrom and Iacobucci [20] stated that customer satisfaction is commonly related to the most important element was the product quality. The quality was strong positive relationships between customer behaviors [21]. Therefore, quality was an aspect of functional value that contributes positively to purchase intention.

Information satisfaction (IS): Information satisfaction refers to consumers' satisfaction with an overall information [22]. The information included acquiring the information of product specs, stores, promotions [23]. Internet shoppers could share information and shopping experiences with those who have the same interest online. The internet provided the most efficient means for consumers to get that information. The information collected could be copied or saved for future comparison. Bakos [24] stated that the internet contained public information resources and a variety of searching tools. Customers are only a few clicks away from receiving abundant information about stores and products online. Consumers were interested in the sites with useful information, personalized content, clear interface, ease and effectiveness of the browsing will also influence consumer decision-making. Therefore, information satisfaction was an aspect of functional value that contributes positively to purchase intention.

2) Emotional value: The emotional value was defined as a perceived utility acquired from a capacity to arouse feelings or affective state. Emotion can be described as feelings or emotional reactions against factors, such as conditions, products, advertisements, promotions and brands [5]. Emotional values are related to reactions that the consumers have against products [25]. Emotional values can emerge in consumption preferences in a positive way such as loyalty, nostalgia, and excitement and in a negative ways such as fear, anger, and guilt [5]. Previous studies found that emotional responses, including sensory pleasure, aesthetic beauty and excitement, to luxury consumption are repeatedly observed [26]. 
Aesthetic (AES): Aesthetic was often classified as a branch of value theory. This classification was curious and in some ways objectionable [27]. Aesthetics refers to the originality, creativity and the richness of the design [28]. Aesthetics involve the perceived visual appeal [29]. They should attract the interest of potential buyers. Aesthetics are a key component of product design. Many customers consider the visual appeal and aesthetics of a product not only for hedonic products, but also for functional products. A key component of hedonic shopping, the aesthetics of an item can affect the purchase intention. Therefore, aesthetic was an aspect of emotional value that contributes positively to purchase intention.

Enjoyment (ENJ): Enjoyment refers to the customers' direct experience of immediate pleasure and joy from using the system [30]. Enjoyment was also a fundamental dimension of online shopping. Hsiao [31] suggested that perceived enjoyment served as an anchor motivation in customers' perceptions of purchasing online music. Earlier research suggested enjoyment and emotion were important drivers of mobile shopping adoption [32]. In additional, Thong et al. [33] found a significant effect of perceived enjoyment on the continued adoption of mobile internet services. Therefore, enjoyment was an aspect of emotional value that contributes positively to purchase intention.

Brand (BRD): Brands were an integral part of today's market. Brands were not just the names of companies, but also identity of the products and services. Moreover, consumers decided to buy something, they did not consider only product but also brand. Previous study suggests that the perceived personality of brands can influence the strength of relationships with consumers [34]. Retailer brand regarding customer purchase intention is a well-known factor that affects success in the e-commerce environment [35]. The rise of the retailer as a brand is considered as one of the most important trends in retailing [36]. Retailer brand, such as store image or reputation, is an important input in the consideration set of purchasing, which influences the consumer decision [37]. Gounaris et al. [38] empirically tested whether delivery of superior customer value enables a brand to achieve better relational outcomes with consumers' behavioral intentions. Consumers holding a high brand consciousness expect that a brand represents status and prestige and, as a result, are willing to purchase luxurious and famous brand-name merchandise [39]. Webster [40] discussed the impact of brand on consumer perceived value with respect to a brand with a value proposition for a retailer. Therefore, brand was an aspect of emotional value that contributes positively to purchase intention.

3) Social value: The social value was defined as a perceived utility acquired from an alternative's association with one or more specific social groups. This obtained social benefit can be positive or negative depending on demographic, socioeconomic and cultural-ethnic groups [5]. Previous research were combining social status, self-image and esteem in an overarching category called social value [41]. Social value arises when one's own consumption behavior serves as a means to influence the responses of others [42].

Social self-image (SSI): It is the perceived capability of an item to enhance one's image in the eyes of others. Strong supporting evidence show self-image congruence explains and predicts different aspects of consumer behavior [43]. People consume products to enhance their social image because a purchase, display, and use of goods can communicate one's symbolic meaning to others. Consequently, the jewelry are their symbolic social meaning. It can help to enhance the representation of selfimage, making it likely that people will purchase a jewelry item as symbolic goods to express and enhance their image. Consumers who have a preference for high prestige have a high regard to enhance their own actual or desired prestigious self-image [44]. Furthermore, customer's social image can be altered by an accumulation or divestment of different products, presenting a possibility of differentiation from others [45]. Therefore, social self-image is an aspect of social value that contributes positively to purchase intention.

Social relationship support (SRS): Social relationship support refers to perceived capability to help form, maintain, and enhance interpersonal relationships. Social networking sites are places in which individuals can find and provide emotional support, companionship, and encouragement. Social networking members create home pages in order to maintain existing relationships [46]. Social networking members expect to attract more visitors with whom they could potentially establish relationships. Arnold and Reynolds [47] pointed out that many people treasure the time spent shopping with friends or family members, and also enjoy social activities while shopping. Wolfinbarger and Gilly [48] believed that the emergence of the virtual community has shifted the social benefits from friends known through the Internet to friends and relatives. Therefore, Social relationship support was an aspect of social value that contributes positively to purchase intention.

4) Security risk (SR): Security risk in online environment refers to the perceptions about security regarding the means of payment and the mechanism for storing and transmission of information [49]. Further, Flavián and Guinalíu [50] propose security risk as the technical aspect of ensuring the integrity, confidentiality, authentication and non-recognition of relationships. Previous research found that security is a key dimension in studying attitude towards online shopping [51]. According to Shim et al. [52] claimed that payment security, privacy, safety, and product guarantees were affected intention to use the internet for purchasing. Customers tend to increase purchases only if they perceive that credit card numbers and other sensitive information are safe.

\section{Conceptual Framework}

A result of the literature review on value framework theory in the context of purchase decision of jewelry items from social networking sites is summarized in Figure 1. The detail explanations of conceptual framework are discussed in the subsequent section. 


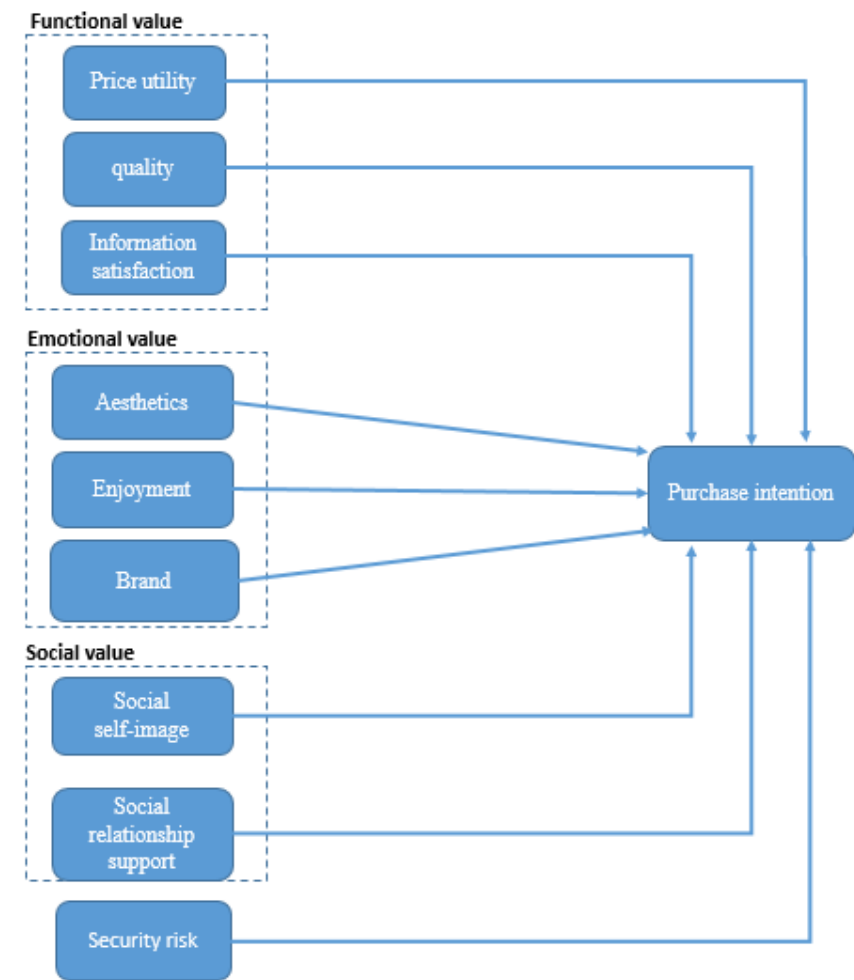

Figure 1. Conceptual framework of purchase decision of jewelry items from social networking sites

\section{Discussion}

This study explores and integrates previous research on value framework approaches through the views of the theoretical perspectives toward developing to be able to image the evolution of applications of value framework theory. Each of factors offers a unique point, it is important to carefully consider the factors from the previous research. Although, the each of value are leading to increase the purchase intention. However, the value perspective only is insufficient to explain the complexities of purchase decision from social networking sites. Then, the study is included additionally by the security risk to the conceptual framework. The conceptual framework is presented in Figure 1, it illustrates the relationships among independent variables (price utility, quality, information satisfaction, aesthetic, enjoyment, brand, social self-image, social relationship support and security risk) with dependent variable (purchase intention).

In addition, the researchers suggest that blending the independent variables together may provide a more useful means of understanding the complex of purchase decision on social networking sites. Consequently, it could explore the compound construct before examining an independent variables are impact on purchase intention.

As previous mentioned, value framework theory has become a useful concept to explain purchase decision. It assists in understanding why customer buy products or not. The theory is frequently considered as the basis to establish and test the propositions, frameworks, and relationships. Researchers can benefit from considering each of the factors when designing conceptual framework. These factors should be given careful attention in future research on purchase decision of jewelry items from social networking sites.

\section{v. Conclusion}

This paper creates two broad conceptual contributions as the following. First, it provides summary description of value factors based on value framework theory and integrates prior research in order to provide greater understanding. Second, it summarizes the conceptual model of purchase decision of jewelry items from social networking sites.

However, the paper presents the first stage of an ongoing research project into the relationship between value factors and purchase decision on social networking sites in order to suggest suitable strategies for jewelry business. The next stage of this research is to conduct factor analysis and explore the relationship through empirical data collection.

Finally, this study indicates that social networking is new source of revenue and also explore the factors based on value framework theory. Examining the factors to purchase decision of jewelry items is crucial for the success of the source of revenue. Therefore, it is important that researchers continue to study on these factors.

\section{References}

[1] Ellison, N. B. (2007). Social network sites: Definition, history, and scholarship. Journal of Computer-Mediated Communication, 13(1), 210-230.

[2] Buettner, R. Getting a Job via Career-oriented Social Networking Sites: The Weakness of Ties. In 49th Annual Hawaii International Conference on System Sciences. Kauai, Hawaii: IEEE.

[3] Huang, J., Boh, W. F., \& Goh, K. H. (2011). From A Social Influence Perspective: The Impact of Social Media on Movie Sales. The 15th Pacific Asia Conference on Information systems (PACIS), (p. 79). Australia.

[4] Digital Advertising Association of Thailand. (2014). Thailand Social Media Landscape 2014. Thailand.

[5] Sheth, J. N., Newman, B. I., \& Gross, B. L. (1991). Why we buy what we buy: a theory of consumption values. Journal of Business Research, 159-170.

[6] Drucker, P. (2001). The next society. . The economist, 52.

[7] Jones, M. A., Mothersbaugh, D. L., \& Beatty, S. E. (2002). Why customers stay: measuring the underlying dimensions of services switching costs and managing their differential strategic outcomes. Journal of business research, 55(6), 441-450.

[8] Xiao, G., \& Kim, J. O. (2009). The investigation of Chinese consumer values, consumption values, life satisfaction, and consumption behaviors. Psychology \& Marketing, 26(7), 610-624.

[9] Schechter, L. (1984). A normative conception of value. Progressive Grocer, executive report, 2, 12-14.

[10] Mathwick, C., Malhotra, N., \& Rigdon, E. (2001). Experiential value: conceptualization, measurement and application in the catalog and Internet shopping environment. Journal of retailing, 77(1), 39-56.

[11] Biswas, A., \& Blair, E. A. (1991). Contextual effects of reference prices in retail advertisements. The Journal of Marketing, 1-12.

[12] Wagner, T. (2007). Shopping motivation revised: a means-end chain analytical perspective. International Journal of Retail \& Distribution Management, 35(7), 569-582.

[13] Stern, A. A. (1989). Pricing and differentiation strategies. Planning Review, 30-35.

[14] Miller, N. (2000). Retail leasing in a web enabled world. Journal of Real Estate Portfolio Management, 6(2), 167-184.

[15] Woodruff, R. B. (1997). Customer value: the next source for competitive advantage. Journal of the academy of marketing science, 25(2), 139-153. 
[16] Clemons, D. S., \& Woodruff, R. B. (1992). Broadening the view of consumer (dis) satisfaction: A proposed means-end disconfirmation model of CS/D. In American marketing association (pp. 209-216).

[17] Albrecht, K. (1992). Only Thing That Matters. Executive Excellence, 9, 7-7.

[18] Monroe, K. B. (1990). Pricing-Making Profitable Decisions, McGraw Hill. New York.

[19] Gale, B. T. (1994). Managing customer value: Creating quality and service that customers can see. New York: Free Press.

[20] Ostrom, A., \& Iacobucci, D. (1995). Consumer trade-offs and the evaluation of services. The Journal of Marketing, 17-28.

[21] Sureshchandar, G. S., Rajendran, C., \& Anantharaman, R. N. (2003). Customer perceptions of service quality in the banking sector of a developing economy: a critical analysis. International journal of bank marketing, 21(5), 233-242.

[22] Crosby, L. A., \& Stephens, N. (1987). Effects of relationship marketing on satisfaction, retention, and prices in the life insurance industry. Journal of marketing research, 404-411.

[23] Wolfinbarger, M., \& Gilly, M. C. (2001). Shopping online for freedom, control, and fun. California Management Review, 43(2), 3455.

[24] Bakos, J. Y. (1997). Reducing buyer search costs: Implications for electronic marketplaces. Management science, 43(12), 1676-1692.

[25] Xiao, G., \& Kim, J. O. (2009). The investigation of Chinese consumer values, consumption values, life satisfaction, and consumption behaviors. Psychology \& Marketing, 26(7), 610-624.

[26] Roux, E., \& Floch, J. M. Le luxe: l'articulation d'une éthique et d'une esthétique in dissociables.

[27] Walton, K. L. (1993). How marvelous! Toward a theory of aesthetic value. The journal of aesthetics and art criticism, 51(3), 499-510.

[28] Lavie, T., \& Tractinsky, N. (2004). Assessing dimensions of perceived visual aesthetics of web sites. International journal of humancomputer studies, 60(3), 269-298.

[29] Cai, S., Xu, Y., Yu, J., \& De Souza, R. (2008). Understanding aesthetics design for E-commerce web sites: a cognitive-affective framework. PACIS 2008 Proceedings, 60.

[30] Mun, Y. Y., \& Hwang, Y. (2003). Predicting the use of web-based information systems: self-efficacy, enjoyment, learning goal orientation, and the technology acceptance model. International journal of human-computer studies, 59(4), 431-449.

[31] Hsiao, K. L. (2011). Why internet users are willing to pay for social networking services. Online Information Review, 35(5), 770-788.

[32] Li, M., Dong, Z. Y., \& Chen, X. (2012). Factors influencing consumption experience of mobile commerce: A study from experiential view. Internet Research, 22(2), 120-141.

[33] Thong, J. Y., Hong, S. J., \& Tam, K. Y. (2006). The effects of postadoption beliefs on the expectation-confirmation model for information technology continuance. International Journal of HumanComputer Studies, 64(9), 799-810.

[34] Aaker, J., Fournier, S., \& Brasel, S. A. (2004). When good brands do bad. Journal of Consumer research, 31(1), 1-16.

[35] Burt, S., \& Davies, K. (2010). From the retail brand to the retail-er as a brand: themes and issues in retail branding research. International Journal of Retail \& Distribution Management, 38(11/12), 865-878.

[36] Grewal, D., Iyer, G. R., \& Levy, M. (2004). Internet retailing: enablers, limiters and market consequences. Journal of Business Research, 57(7), 703-713.

[37] Macdonald, E. K., \& Sharp, B. M. (2000). Brand awareness effects on consumer decision making for a common, repeat purchase product:: A replication. Journal of business research, 48(1), 5-15.

[38] Gounaris, S. P., Tzempelikos, N. A., \& Chatzipanagiotou, K. (2007). The relationships of customer-perceived value, satisfaction, loyalty and behavioral intentions. Journal of Relationship Marketing, 6(1), 6387.

[39] Liao, J., \& Wang, L. (2009). Face as a mediator of the relationship between material value and brand consciousness. Psychology \& Marketing, 26(11), 987-1001.

[40] Webster, F. E. (2000). Understanding the relationships among brands, consumers, and resellers. Journal of the academy of marketing science, 28(1), 17-23.

[41] Bourdeau, L., Chebat, J. C., \& Couturier, C. (2002). Internet consumer value of university students: E-mail-vs.-Web users. Journal of Retailing and Consumer Services, 9(2), 61-69.

[42] Holbrook, M. B. (2006). Consumption experience, customer value, and subjective personal introspection: An illustrative photographic essay. Journal of Business Research, 59(6), 714-725.
[43] He, H., \& Mukherjee, A. (2007). I am, ergo I shop: does store image congruity explain shopping behaviour of Chinese consumers? Journal of Marketing Management, 23(5-6), 443-460.

[44] Husic, M., \& Cicic, M. (2009). Luxury consumption factors. Journal of Fashion Marketing and Management: an international journal, 13(2), 231-245.

[45] Brady, M. (1992). Heavy metal: the social meaning of petrol sniffing in Australia. Aboriginal studies press.

[46] Walker, K. (2003). It's difficult to hide it. The presentation of self on Internet home pages. Qualitative Sociology, pp. 99-120.

[47] Arnold, M. J., \& Reynolds, K. E. (2003). Hedonic shopping motivations. Journal of retailing, 79(2), 77-95.

[48] Wolfinbarger, M., \& Gilly, M. C. (2001). Shopping online for freedom, control, and fun. California Management Review, 43(2), 3455.

[49] Kolsaker, A., \& Payne, C. (2002). Engendering trust in e-commerce: a study of gender-based concerns. Marketing Intelligence \& Planning, 20(4), 206-214.

[50] Flavián, C., \& Guinalíu, M. (2006). Consumer trust, perceived security and privacy policy: three basic elements of loyalty to a web site. Industrial Management \& Data Systems, 106(5), 601-620.

[51] Shih, H. P. (2004). An empirical study on predicting user acceptance of e-shopping on the Web. Information \& Management, 41(3), 351368.

[52] Shim, S., Eastlick, M.A., Lotz, S.L., Warrington, P., 2001. An online prepurchase intentions model: the role of intention to search. Journal of Retailing 77 (4), 397-416.

About Author (s):

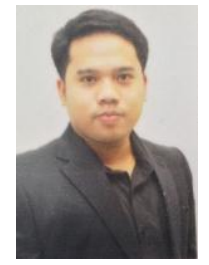

Paramin Chuangmane is Assist Vice President in IT Dept. Bank of Ayudhya. $\mathrm{He}$ was studying master degree in the major of management and strategy, College of Management Mahidol University. His research interests are in the areas of social networking, virtual community and information technology management.

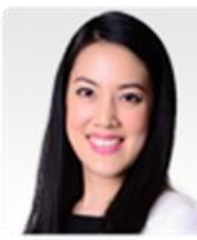

Dr. Prattana Punnakitikashem is an assistant professor of Operations Management at College of Management, Mahidol University where she teaches operations management and strategic management decision making. Her research interests are in the area of operations management including lean management, process improvement and supply chain, healthcare and wellness management, and technology \& innovation management. She has published numerous publications and has been a speaker at several international conferences. 